\title{
Jesuit Sanctity: Hypothesizing the Continuity of a Hagiographic Narrative of the Modern Age
}

\author{
Franco Motta \\ Dipartimento di Studi Storici, Università di Torino, Turin, Italy \\ franco.motta@unito.it \\ Eleonora Rai \\ Faculty of Theology and Religious Studies, Research Unit History \\ of Church and Theology, Leuven, Belgium \\ eleonorarai@kuleuven.be
}

\begin{abstract}
The introduction to this special issue provides some considerations on early modern sanctity as a historical object. It firstly presents the major shifts in the developing idea of sanctity between the late medieval period and the nineteenth century, passing through the early modern construction of sanctity and its cultural, social, and political implications. Secondly, it provides an overview of the main sources that allow historians to retrace early modern sanctity, especially canonization records and hagiographies. Thirdly, it offers an overview of the ingenious role of the Society of Jesus in the construction of early modern sanctity, by highlighting its ability to employ, create, and play with hagiographical models. The main Jesuit models of sanctity are then presented (i.e., the theologian, the missionary, the martyr, the living saint), and an important reflection is reserved for the specific martyrial character of Jesuit sanctity. The introduction assesses the continuity of the Jesuit hagiographical discourse throughout the long history of the order, from the origins to the suppression and restoration.
\end{abstract}

\section{Keywords}

early modern sanctity - Jesuit hagiography - martyrdom - theological legitimization - missionaries - Jesuit identity - Jesuit suppression - Jesuit restoration 
Sanctity, as a cultural phenomenon, is neither stable nor unequivocal in nature. It sheds its skin; it changes meaning and function according to the context in which it is sought out, recognized, and, finally, canonized. Of course, sanctity possesses a more intimate, unchangeable core, a core that is common not only to the entire history of Christianity beginning with its very origins, but also to the wider arena of signifiers referring to the human perception of the sacred: contact with the sphere of the supernatural, and thus the mediation between the supernatural sphere and the sphere of nature, as well as the suspension of the laws that regulate nature through miracles. At the same time, however, sanctity can be recognized as a historical object, bound to linguistic and symbolic registers that operate in accordance with the environment from which they derive meaning.

The space in which the divine intersects with the human is also expressed on a historical level, that is to say, this space materializes in the languages associated with the historical context of belonging. If, as anthropologist Clifford Geertz (1926-2006) argues, religion is to be understood as a system of symbols guiding human behavior, then the symbolic system of sanctity is to be decoded through registers that are tied to specific epochs, geographical areas, and social needs. ${ }^{1}$ To provide a banal example, the fasting and contempt for the body that were so central to late-medieval figures of holiness eventually lost much of their importance as criteria for evaluating contemporary sanctity, which, in turn, is instead largely focused on ideals of social commitment or dedication to an earthly idea of justice.

The symbolic system of sanctity has unquestionably undergone an endless process of redefinition spanning the entire history of Christianity. With regard to our focus here, that system underwent profound changes at two key moments in the history of Western culture. One of these moments was the pivotal period between the late Middle Ages and the early modern period; this change occurred in response to two factors: first, the widespread emergence of lay spirituality, as people's religious needs no longer proved to be satisfied by the devotional practices of monastic and mendicant orders and, later, in response to the challenge that the Protestant Reformation posed to the cult of the saints itself. The second shift, which took place between the late eighteenth and the

1 An initial overview of the topic explored in this introduction was presented by Motta and Rai at the conference $A$ la luz de Roma: Santos y santidad en el barroco iberoamericano (September 17-20, 2018). See Franco Motta and Eleonora Rai, "Strategie di santità: La politica delle canonizzazioni dei gesuiti fra antica e nuova Compagnia (XviI-XX secolo)," in A la luz de Roma: Santos y santidad en el barroco iberoamericano, ed. Fernando Quiles García et al., 2 vols. (Rome: RomaTre-Press, 2020), 1:91-106. Clifford Geertz, "Religion as a Cultural System," in Geertz, The Interpretation of Cultures (New York: Basic Books, 1973), ch. 4. 
second half of the nineteenth centuries, specifically represented a response to the process of secularization and the growing importance of mass society. ${ }^{2}$

There is thus a specifically modern hagiographic discourse that has certain distinctive features in terms of both form and content. As far as form is concerned, the most important element is arguably the increasing use of the sacred as an instrument for exercising hegemony over collective culture and behavior. From this point of view, holiness, together with the space, time, and narratives through which it was manifested, came to play a central role in the competition between powers and in the confessionalization processes that distinguish the early modern period. This centrality of holiness is evidenced by, for example, the proliferation of biographies and printed images of saints and blessed by the numerous artistic representations, places of worship, relics, and commercial artefacts that radically reshaped the Catholic devotional universe in the period from the end of the sixteenth to the end of the nineteenth century.

Obviously, there are also elements of continuity that position early modern sanctity on the same trajectory of development as its late-medieval version. The first example that comes to mind is the growing centralization, in the hands of the pope, of the tools of legitimacy guaranteed by the power to proclaim saints, with the progressive construction of a monopoly over the resources of the sacred beginning in the fourteenth century-one of the elements of the lengthy building process for the doctrine of papal infallibility. ${ }^{3} \mathrm{We}$ must also recognize, however, that it was between the sixteenth and the seventeenth centuries that this process really accelerated: it was precisely during the crucial turn of the decades following the Council of Trent $\left(1545^{-63}\right)$ that the

2 Literature on the history of sanctity in the Middle Ages and the early modern period is already quite extensive; of the many titles that could be cited, a select few are: Jean-Michel Sallmann, Naples et ses saints à l'âge baroque (1540-1750) (Paris: Puf, 1994); Brad S. Gregory, Salvation at Stake: Christian Martyrdom in Early Modern Europe (Cambridge, MA: Harvard University Press, 1999); Francesco Scorza Barcellona et al., eds., Storia della santità nel cristianesimo occidentale (Rome: Viella, 2005), and more generally the titles included in the "Sacro/santo" series by the same publisher; Ronald Finucane, Contested Canonizations: The Last Medieval Saints, 1482-1523 (Washington, DC: The Catholic University of America Press, 2011); Robert Bartlett, Why Can the Dead Do Such Great Things?: Saints and Worshippers from the Martyrs to the Reformation (Princeton: Princeton University Press, 2013).

3 Regarding this topic, see Donald S. Prudlo, Certain Sainthood: Canonization and the Origins of Papal Infallibility in the Medieval Church (Ithaca, NY: Cornell University Press, 2015). On the modern age, see Pierluigi Giovannucci, Canonizzazioni e infallibilità pontificia in età moderna (Brescia: Morcelliana, 2008); Riccardo Saccenti, "Reforming Canonization after the Council of Trent: Saints and Martyrs as Models of a Pure Christian Life," in Reframing Reformation: Understanding Religious Difference in Early Modern Europe, ed. Nicholas Terpstra (Toronto: Centre for Reformation and Renaissance Studies, 2020), 51-68. 
Roman Curia developed a precise administrative and juridical apparatus (the Congregation of Rites, which was created in 1588 as part of the reform of Sixtus $\mathrm{V}$ [r.1585-90], and the development of the beatification process as a necessary premise to canonization) through which to implement, via solid bureaucratic mechanisms, the ideas of a centralized church government and strict control over Catholic orthodoxy, which are so specific to the post-Tridentine papacy. ${ }^{4}$

It is precisely thanks to the continuous operation of this apparatus for governing of the supernatural that historians who study early modern and modern sanctity have access to such rich veins of source material, extraordinary in terms of magnitude and variety. This corpus includes not only hagiography strictly speaking, that is, biographical narratives, collections of letters and documents, and iconographic materials intended for places of worship and circulation among the faithful, but also and even more so the proceedings of the canonical processes themselves; such proceedings were produced in local communities and transmitted to the Roman Congregation of Rites to be examined and discussed.

This vast documentary forest of judicial records simultaneously attests two realities: the cultural multiplicity of local "Catholicisms" - to quote historian Paola Vismara $(1947-2015)^{5}$-in dioceses around the world, and the work of centralization and normalization carried out by the Roman center; it was a religious Babel rendered uniform through the linguistic and conceptual filters of the curia. Observed from the perspective of holiness, this "religious field," with its thaumaturgical capital and plurality of actors competing for such capital, thus appears to be an extraordinarily fertile ground for research prospects. ${ }^{6}$ As historian of religion Simon Ditchfield has noted, "hagiography—understood in the broader definition that encompasses canonisation trial records-is a substantially unwritten chapter in the histories of early modern science, politics, and even religion itself." ${ }^{7}$ Furthermore, just imagine how much material of

4 In relation to this point, see Miguel Gotor, I beati del papa: Santità, Inquisizione e obbedienza nella prima età moderna (Florence: Olsckhi, 2002).

5 Paola Vismara, Cattolicesimi:Itinerari sei-settecenteschi (Milan: Edizioni Biblioteca Francescana, 2002).

6 A brilliant example of research that is based on such sources can be found in Eric Suire, La sainteté française de la Réforme catholique (XVI $-X V I I I^{e}$ siècles): D'après les textes hagiographiques et les procès de canonisation (Pessac: Presses universitaires de Bordeaux, 2001). As for the "religious field," we refer of course to the notion introduced by anthropologist Pierre Bourdieu (1930-2002) that we consider to be particularly useful in the study of sanctity and its social meanings: "Genèse et structure du champ religieux," Révue française de sociologie 12, no. 3 (1971): 295-334.

7 Simon Ditchfield, "Thinking with Saints: Sanctity and Society in the Early Modern World," Critical Inquiry 35, no. 3 (2009): 552-84, here 554. 
great interest for modern and contemporary anthropology and religious sociology might lie in the witness statements about miracles and in the accounts of candidates for sanctity that are contained in trial records.

The interplay between politics and religion, the exercise of social and cultural hegemony, and the ability to bring together disciplines and languages have been an integral part of the work performed by the Society of Jesus. It would be surprising, therefore, not to see Jesuits at the forefront of the history of early modern sanctity. And such is indeed the case: not only has hagiographic discourse been central to the Jesuit cultural program, but, vice versa, this program has also contributed in fundamental ways to the evolution of hagiography. It suffices to think, for example, of Virgilio Cepari (1563-1631), authoritative postulator of the Society of Jesus and promoter of some of the great causes of the order at the turn of the seventeenth century, from Luigi Gonzaga (1568-91) to Jan Berchmans (1599-21) and Robert Bellarmine (15421621). Cepari authored what is considered the first systematic treatise on canonization procedures, the manuscript Directorium canonizationis sanctorum (Directory for the canonization of saints, c.1605), which served as one of the main sources for Benedict XIV's (r.1740-58) De servorum Dei beatificatione (On the beatification of God's servants).

In light of these considerations, is it possible to speak of a particular Jesuit sanctity, as we speak of Jesuit theatre or Jesuit science? In other words, is there a hagiographic model specific to the Society, a model partially distinct from the earthly manifestations of the sacred belonging to Catholicism in general? It is our hope that this issue of the Journal of Jesuit Studies will help answer this question.

A prominent feature of Jesuit hagiographic discourse and strategies is undoubtedly that they contain important elements of continuity between the old and the new Society. Most of the saints and blessed who had lived before the order was suppressed in 1773 were in fact elevated to the altars between the nineteenth and the twentieth centuries, in particular beginning with the pontificate of Pius IX (r.1846-78), with two canonizations and twenty-six beatifications between 1846 and 1872 . If we bear in mind that virtually all canonization processes of the pre-suppression Jesuits were launched shortly after their deaths, suspended before or during the period of suppression, and then reopened, in some cases more than a century later, then it is clear that hagiographic discourse exerted considerable influence in the reconstitution of the Society's historical identity.

One fact is worth noting, however: there are almost no studies to date that investigate the hagiographic strategies of the Society as a phenomenon with its own coherence and historical profile. While there is no lack of research into 
individual canonizations and beatifications, or the methods used to celebrate and propagandize them, the theme of sanctity as the object of a precise religious policy within the wider activity of the order has yet to be studied. ${ }^{8}$ For this reason we would like to briefly outline some possible manifestations of this phenomenon.

Naturally, Jesuit hagiographic discourse should not be understood as unique in the cultural universe of early modern Catholicism, and in particular in that historical phenomenon known as the Counter-Reformation, or the Tridentine Reform. In fact, such discourse converged with the broader history of the great revival in epiphanies of the sacred - not only holiness, but also wonders, apparitions, possessions, and all the resources offered by the thaumaturgical arsenal of Christian culture-that characterized the church's commitment to social hegemony from the Council of Trent to the French Revolution (1789) and beyond, even up to the dawn of the twentieth century in some areas. From this point of view, the strategies and objectives of the Society of Jesus were the same as those of other congregations that had been born out of the sixteenth-century church, such as the Theatines, Capuchins, and Oratorians, or the same as those of the new subjects of power such as the great reforming bishops of the Tridentine age. Think, for example, of the parallel and common events surrounding the canonizations of three eponymous saints of Catholic modernity: Ignatius of Loyola, Philip Neri (1515-95), and Charles Borromeo (1538-84).

This phenomenon has been extensively studied. In the years between the sixteenth and the seventeenth centuries, the pressure from the postulators of these three candidates' causes - candidates whose alleged sainthood was singularly recent and uncorroborated by a lengthy tradition of worship, but

8 Studies investigating the processes and cult of several men of the Society (Stanisław Kostka [1550-68], Pierre Favre [1506-46], Berchmans, Gonzaga, Peter Canisius [1521-97] to mention only the most famous, as well as Ignatius and Xavier, of course) can be found throughout the collection of Archivum historicum Societatis Iesu. Additional case studies were undertaken by Bernard Dompnier, "Les jésuites et la dévotion populaire: Autour des origines du culte de saint Jean-François Régis (1641-1676)," in Les Jésuites parmi les hommes aux XVIe et XVIIe siècle, ed. Geneviève and Guy Demerson, Bernard Dompnier, and Annie Regond (Clermont-Ferrand: Faculté des Lettres et Sciences humaines de l'Université de Clermont-Ferrand II, 1987), 295-308; and Eleonora Rai, "The 'Odor of Sanctity': Veneration and Politics in Leonard Lessius's Cause of Beatification (Seventeenth-Twentieth Centuries),"Journal ofJesuit Studies 3, no. 2 (2016): 238-58, https://brill.com/view/journals/jjs/3/2/article-p238_4.xml (accessed September 19, 2021). A more general overview on Jesuit canonization processes is provided by Anna Ohlidal and Stefan Samerski, eds., Jesuitische Frömmigkeitskulturen: Konfessionelle Interaktion in Ostmitteleuropa 1570-1700 (Stuttgart: Franz Steiner, 2006); Samerski, “Wie im Himmel so auf Erden?”: Selig- und Heiligsprechung in der katholischen Kirche 1740 bis 1870 (Stuttgart: Kohlhammer, 2002), 251-310. 
which, on the other hand, relied on substantial popular support-generated tension in the ecclesiastical hierarchies that in turn triggered the opposition of the Dominicans, an older order loyal to protecting orthodox procedures. This was, in other words, a conflict over the control of the legitimation resources ensured by canonizations, a conflict, which led Clement VIII (r.1592-16o5) to create the Congregation of the Blessed in 1602 and which led the Holy Office and Urban VIII (r.1623-44) to later issue their 1625 decrees confirming the Holy See's strict monopoly of all procedures for verifying sanctity.

The fact is, however, that in this case, too, the Society of Jesus was set apart by its adoption of propaganda strategies that were unprecedented and, for the time, radical: in 1601 , Clement viII put a stop to the vast production and circulation of images of Ignatius that lacked the imprimatur; in 16o9, in the face of the massive celebrations organized on the occasion of his beatification, a memorial delivered to the Holy Office denounced the Jesuits' habit of "filling" the biographies of their founder "with miracles," of visiting the homes of the sick so that they might appeal to him, and of making "more clamor and solemnity than all the other churches of all the canonized saints together." ${ }^{\prime 9}$ On the whole, we believe that the policy of sanctity that the Society of Jesus pursued between the end of the sixteenth and the beginning of the twentieth centuries had at least three particular characteristics we now describe.

The first was the Jesuits' ability to employ a multiplicity of hagiographic models, some of which were new to the spectrum of holy figures typical of traditional devotion and which were intended to serve different strategies. Such strategies included, for example, the following: maintaining a grip on the popular classes, as in the case of Francesco De Geronimo (1642-1716) and Bernardino Realino (1530-1616); cultivating agreement with the aristocracy, as in the case of Francisco de Borja $(1510-72)$ and Gonzaga; providing theological legitimation, as in the case of Bellarmine, Leonard Lessius (1553-1623), and Canisius; and ensuring hegemony over certain geographical areas and social identities, as in the case of Andrzej Bobola (1591-1657) and Pedro Claver (15801654). ${ }^{10}$ Moreover - and this is probably one of the most innovative aspects of the Jesuit canonization policy—the Jesuits celebrated the simple cursus

9 Gotor, Beati del papa, 235 .

10 On theology as a key element of Jesuit identity, see, among other studies, Franco Motta, "Jesuit Theology, Politics, and Identity: The Generalate of Acquaviva and the Years of Formation," in The Acquaviva Project: Claudio Acquaviva's Generalate (1581-1615) and the Emergence of Modern Catholicism, ed. Pierre-Antoine Fabre and Flavio Rurale (Chestnut Hill, MA: Institute of Jesuit Sources, 2017), 353-74; Eleonora Rai, "Ex meritis praevisis: Predestination, Grace, and Free Will in Intra-Jesuit Controversies (1587-1613), Journal of Early Modern Christianity 7, no. 1 (2020): 111-50. 
within the order, as seen from the cases of Kostka and Berchmans (it should be noted that, as early as the mid-sixteenth century, another enemy of the Society, Melchior Cano [1509-6o], condemned the Jesuits' tendency to consider the simple fact of belonging to the order to be an indication of sanctity).

The article by Pierluigi Giovannucci in this volume is dedicated to the 1666 biography of Giulio Brignole Sale $\left(1605^{-62}\right)$ that was written by Giovanni Maria Visconti (1612-84). The article effectively shows the importance Jesuit hagiographic narrative attached to the Society's acquiring a leading representative of the Genoese power elite in the mid-seventeenth century. Similarly, Marie-Elizabeth Ducreux's article, which analyzes the way in which the Habsburgs of Austria promoted devotion to prominent figures such as Loyola, Xavier, and Gonzaga, highlights the profound political and diplomatic significance that Jesuit holiness had in the Austrian territories, a key area of the Counter-Reformation.

The second feature that may be identified is the Jesuits' ability to use hagiographic discourse flexibly, adapting it to the demands of historical change and sometimes varying the underlying meaning of individual models of sanctity. One example is particularly enlightening in this regard.

The process of gathering information to launch the canonical process for Cardinal Bellarmine began only a few days after his death in September 1621. Bellarmine's month-long agony became an example of the Christian art of dying well, an example that attracted many cardinals and even Pope Gregory xv (r.1621-23) himself while on pilgrimage; but it is worth noting that Bellarmine, while he was still alive, had somehow planned his own hagiographic persona, the fairly rare persona of a cardinal saint. By deploying the resources of the sacred, the Society thus openly claimed the status of a reformer, one reforming the summit of the church from within. The trial ran into two roadblocks, in 1678 and again in 1753 , due to strong internal opposition within the Congregation of Rites. In both cases, however, Bellarmine's sanctity was closely, if implicitly, linked to the sanctity of his doctrine, and in particular to the political theory of the potestas indirecta, which reaffirmed that the Apostolic See's jurisdiction over all moral and religious matters was superior to that of secular power. Halted in the middle of the eighteenth century, the cardinal's cause could not be resumed until 1918. In the meantime, however, his complete works were reprinted on the occasion of the First Vatican Council (1869-70), as a doctrinal aid for drafting the dogma of papal infallibility in 1870. Finally, his 1923 beatification, 1930 canonization, and 1931 proclamation as doctor of the church all reference his role of confessor as exemplary in the struggle against atheism and materialism, a struggle that was set in the new climate of agreement between 
the Holy See and the Italian government established by the Fascist regime in 1929 with the mediation of the Italian Jesuit Pietro Tacchi Venturi (1861-1956).

A third peculiarity of Jesuit sanctity is its markedly martyrial character. Currently, the Society counts about thirty-five canonized martyrs and about 140 beatified martyrs from the general calendar of the Society, while there are about twenty saints and blessed who did not suffer martyrdom. ${ }^{11}$ Moreover, it is significant that the more recent Diccionario histórico de la Compañia de Jesús contains no entry for "saints," "sanctity," or "canonizations," although there are detailed entries (twenty pages in total) about the Canadian martyrs, the martyrs of Ethiopia, the martyrs of Kassa (Košice), the martyrs of the French Revolution, the Mexican martyrs of Tepehuanes, the martyrs of Salsete in Goa, the martyrs of Valencia, the martyrs of Brazil, the martyrs of Paraguay, the martyrs of Japan, the martyrs of Great Britain, and the martyrs of Micronesia.

We know, of course, that the celebration of martyrdom is an important element in early modern religious discourse, especially in the age of the CounterReformation. Nevertheless, in practice the hierarchical church at that time favored canonization models that represented a glorious (rather than suffering) Catholicism, in primis for the founders of new religious orders.

The fact is, however, that martyrdom appears to be absolutely central to the Society's strategies of canonization and is by no means limited to the age of the confessional conflict and the great missionary expansion; rather, the centrality of martyrdom to the canonization process is endowed with such historical continuity that martyrs constitute one of the central figures the new Society promoted as it was closely engaging with the challenges of the modern world. ${ }^{12}$ Jean-Pascal Gay, in analyzing (in this issue) Théophile Raynaud's De martyrio per pestem (1630), identifies an unprecedented mode of martyrdom, namely, death after caring for plague victims. This contribution clearly shows the high stakes involved in theologically redefining the model of martyr to meet the requirements imposed by the historical context of the Counter-Reformation and Catholic revival. At the same time, Leonardo Cohen demonstrates that the

11 Data collected on https://www.vatican.va/roman_curia/pontifical_academies/cultmartyrum/martiri/oo2.html (accessed May 12, 2021). See also an old statistical profile by Father Jan Szymusiak, dating back to 1974 and thus not updated with the most recent data, but still interesting: In Cristo Gesù: Profili dei santi e beati della Compagnia di Gesù (Milan: Àncora, 1974).

12 Concerning the renewed importance of martyrdom in the Counter-Reformation age, see Gregory, Salvation at Stake, 250 ff.; Camille Collin, "Entre politique et religion: La martyrologie au XVI e siècle," Revue d'histoire de l'Église de France 104 (2018): 33-55. 
theme of martyrdom has been used as a way of granting meaning to a narrative of defeat, namely, to the shipwreck of the mission to Ethiopia in the 1930s.

The centrality of martyrdom to canonization is a very complex issue, however, and one that involves intrinsic contradictions. Pierre-Antoine Fabre, with his characteristic ability to decipher meanings that are not immediately evident, shows in the afterword to this special issue the extent to which the theme of martyrdom has represented an instrument well suited to multiple uses. As such, it entails a component of risk: while constituting a powerful means of legitimation through hagiographic narration, and historiographic narration more generally (as Fabre properly notes in relation to the Society's historiographic silence during the nineteenth century), the appeal to martyrdom also bears with it the prospect of failure, the kind of defeat that found its most painful expression in the suppression of the order.

The origin of the Society's category of martyrdom, a category that is extremely useful for those who desire a broad overview of the cultural and spiritual history of the Jesuits, is an even more complex issue. The idea of martyrdom as the highest degree of imitatio Christi (it must be kept in mind that dying for one's faith in Christ was a keystone of early Christianity) derives from the adoption of Paul's (d. c.64) theology of the cross-the concept of stultitia crucis (folly of the cross) - by Ignatius, as it appears in the Spiritual Exercises.

Such a doctrine-in addition to both the offering of oneself and the contemplation of the passion - provides the theological and spiritual foundation for the original "Jesuit mind." This mindset and the desire to shed one's blood for Christ emerge from a variety of records, including hagiographic sources and thousands of indipetae - Jesuit applications for overseas missions.

Although this spirituality was developed by Ignatius himself, it was probably the missionary spirit (which was also directed to areas that had embraced the Protestant Reformation) that inflated the desire for martyrdom within the Society, thus transforming that desire into a core value throughout the entire history of the order. It is widely believed that the persecutions suffered by the English Jesuit martyrs in the 158 os inaugurated a period characterized by a tangible, concrete desire for martyrdom within the Society; previously this desire had probably not been a crucial element in the Jesuit vocation, as shown in a survey promoted by Jerónimo Nadal (1507-80) in the Iberian provinces during the 156 os. ${ }^{13}$

A few years later, the paradigm of the English martyrs became a model to be followed, making the Ignatian Christ-mimetic spirituality real and

13 Alejandro Cañeque, "Mártires y discurso martirial en la formación de las fronteras misionales jesuitas," Relaciones: Estudios de historia y sociedad 37, no. 145 (2016): 13-61, here 20-21. 
practicable. Before them, the only violent death registered during the first years of the order-namely, the killing of the so-called protomartyr and missionary Antonio Criminali (1520-49) in India-had not been portrayed as an exemplary case by the Jesuit Curia due to the doubtful circumstances of his death. In effect, Criminali's death, which he had fervently desired and concretely looked for, did not conform to the traditional, legal requirement for a violent death, if the death is to be considered a martyrdom. ${ }^{14}$

Alongside the categories described above, corresponding to the main canonization strategies promoted by the Society, there is also a transversal category, that of the "living saint," which is aimed at legitimizing the work that the order has carried out in its various arenas of action. This category pertains to the general history of the church (and to the primitive church in particular), and various religious orders have in turn, more or less deliberately, made it their own: for example, the Redemptorist Gerardo Majella (1726-55) and the much more famous Capuchin Pio da Pietrelcina (1887-1968).

We would like to outline here two case studies that illustrate specific canonization strategies on the part of the Society. Albeit moving in opposite directions, they both belong to the category of the living saint. The cases in question are the theologian Leonard Lessius (1554-1623), who worked in late sixteenth-century Leuven, and Francesco De Geronimo, a popular missionary and preacher who died in Naples in 1716.

The biographies of these two Jesuits are united by a very important common element: both figures were considered to be living saints. Upon their death, a cult of veneration surrounding these figures exploded, manifesting itself on the one hand in a race to secure their relics, believed to host the charismatic power of the holy body after death, and on the other hand in a proliferation of miracles said to have been achieved through the intercession of these two prospective saints.

14 Martyrdom in odium fidei needs to be verified according to legal norms rooted in Augustine's $(354-430)$ thought and codified during the early modern period by Urban viII in the 1620 s and 1630s, and subsequently by the influential work of Prospero Lambertini (later Benedict XIV), De servorum Dei beatificatione et beatorum canonizatione. When it comes to dealing with Catholic sainthood, we must therefore also keep in mind its legal dimension, together with its religious and social dimensions. On the juridical apparatus for the causes for canonization, see Pierluigi Giovannucci, "Il concetto storico-giuridico di martirio in Prospero Lambertini," Rivista di storia del cristianesimo 15, no. 2 (2008): 341-58; Giuseppe Dalla Torre, "Santità ed economia processuale: L'esperienza giuridica da Urbano viII a Benedetto XIV," in Gabriella Zarri, ed., Finzione e santità tra medioevo ed età moderna (Turin: Rosenberg e Sellier, 1991), 231-63. On the case of Criminali, see Rai, "La legge e il martirio: Morte e normativa nel processo di canonizzazione del 'protomartire' gesuita Antonio Criminali (XVI-XX secolo)," Lexia 31 (2019): 205-44. 
The case of Lessius certainly represents an effort towards theological legitimation. This particular attempt, however, failed; in reality it was only enacted by a part of the order and was opposed by the superior general himself. Moreover, this case also sheds light on the modern church's choices in matters of canonization and the powerful opposition to the Society in curial circles between the seventeenth and early twentieth centuries.

Hagiographic sources from the first half of the seventeenth century describe Lessius as an ascetic and a key player in mystical and ecstatic phenomena, as a person endowed with gifts of an exorcist, great illumination, and the ability to discern. It must be noted, however, that he was above all a theologian who ended up being embroiled during the 158 os in heated theological controversies over the notions of grace and free will. He was accused of Pelagianism or semi-Pelagianism by the doctors of the Faculty of Theology at Leuven, home to Michael Baius (1513-89), whose doctrine had already been condemned. As we might well imagine, the Leuven theologians proposed a pessimistic and rigidly Augustinian theology of grace, which was very distant from the doctrine variously promoted by Jesuit (usually Scholastic) theologians such as Lessius and Luis de Molina (1535-16oo), a version imbued with Christian humanism and open to the possibility of a good use of free will. ${ }^{15}$

Although the case was resolved by a papal bull declaring Lessius's doctrine to be sound and free of error, the dispute dragged on for quite some time and resurfaced, in very similar terms, shortly afterwards in the De auxiliis dispute between the Society of Jesus and the Order of Preachers. Beyond the details of the dispute, our point here is that figures such as Lessius and Molina had caused doctrinal accusations of a certain importance to be brought against the Jesuits. So much so, in fact, that the leadership of the Society asserted its distance from them and censored some of their works.

The cause for Lessius's canonization was supported on several occasions by the Flemish Jesuits, whose milieu was rather parochial in scope. They transformed him into a sort of symbol of resistance against the theses posited by the theologians of Leuven the Jesuits considered to be close to heresy in the same

15 It must be remembered that the sixteenth-century theological panorama at Leuven's Faculty of Theology was complex. In the 158 os, Baius still had opponents within that institution, and Leuven theologians of the previous generation, such as Ruard Tappert (1487-1559), had even fostered a doctrine of grace that was less influenced by strict Augustinianism, to the point that the Jesuits had been invited to settle in Leuven by Tapper himself. See Mathijs Lamberigts, "The Dispute between the Louvain Faculty of Theology and the Jesuits (1587-1588): Solus Augustinus versus Thomist Positions," in Eine Autorität für die Dogmatik?: Thomas von Aquin in der Neuzeit; Festschrift für Leonhard Hell, ed. Benjamin Dahlke and Bernhard Knorn (Freiburg: Herder, 2012), 32-46. 
way that Baius and Jansenius were. In reality, Lessius's reputation for holiness never succeeded in making its way beyond the Spanish Netherlands.

The cause then ran aground because various Catholic circles, especially the Roman ones (the Dominicans, for example), were opposed to a doctrine of grace that they treated as similar-in a completely erroneous way-to the doctrine of the entire Society. Faced with the pressure brought by the postulators between the late nineteenth and early twentieth centuries, a provision by the superior general Luis Martín (in office 1892-1906) prescribed that the cause be dropped if there were evidence of doctrinal divergence between the positions of Lessius and Bellarmine, the latter's cause having been reopened during that period. The superior general was perfectly aware that Bellarmine's canonization would have a universal scope and entail decisive theological legitimation for the Society; by contrast, the disputes that had plagued Lessius and, by extension, the Society as a whole, represented too great an obstacle.

The second case study we briefly introduce here, which will be extensively presented by Motta and Rai in this special issue, is that of Francesco De Geronimo, an example of the Jesuit canonization strategy that looked to the subordinate classes and to the model of the popular missionary saint, that is, to the model of preachers who led exemplary lives and left a deep mark on the areas in which they carried out their missions, thereby achieving an important social role. De Geronimo actively worked for social pacification, was sought out for his acclaimed prophetic skills (although to modern observers these insights seem like simple common sense) and dedicated himself assiduously to the apostolate. The sources collected for the canonization process also identify a succession of miracles that De Geronimo supposedly performed.

These activities attracted enormous popular devotion while De Geronimo was still alive, devotion that manifested itself at the moment of his death. Upon hearing that he had died, the crowd rushed to the funeral chamber to touch the body of a person considered to be a living saint, and a number of miraculous healings were immediately recorded. His confrères, in the face of such veneration, had evidently begun to look upon De Geronimo (while still alive) as a sure candidate for cause for canonization. This expectation is the only explanation for the remarkable speed with which the Jesuit confrères wrote their first reports about the dead man, cloaked in holiness, and sent them to the General Curia, as well as for the amount of information regarding the supposed miracles that occurred both during his life and post mortem, and for the confrères' rush to collect relics from De Geronimo's body and clothing immediately after his passing. 
The suppression of the Society greatly affected the self-perception of the restored order and, consequently, its policy on sanctity. The idea of suppression as a time of tribulation and true martyrdom, an idea that generals Lorenzo Ricci (1703-75; in office $175^{-5}$-53) and Jan Philipp Roothaan (1785-1853; in office 1829-53) promoted, pushed the Society's General Postulation to focus on two fronts: on one hand, the causes of missionary martyrs, who were emblematic of the persecution that the Society had suffered, particularly when facing the socio-political changes of modernity and in mission territories. On the other hand, the General Postulation focused on causes, some of which had been opened centuries before, of the figures who had made the old Society one of the most influential orders of the early modern church in terms of theological, doctrinal, and pastoral activity. Indeed, during Roothaan's generalate, which also coincided with the reopening of old causes, the old Ignatian spirit of evangelization entered a new, global season of expansion, reaching as far as the antipodes of the Roman General Curia.

To conclude our introduction to this special issue, we would like to highlight two elements central to the role of sanctity in the long history of the Society of Jesus. One is the clear continuity discernable in Jesuit hagiographic trends; the other is the efficiency shown by the order in strategically adapting different models of sanctity throughout its own history and throughout the broader prospect of early modern church history.

Exemplary models, canonization strategies, and the very idea of sanctity necessarily involve deep meanings, each needing to be placed in its historical context. This special issue contributes to our understanding of how the Society of Jesus-among the most ingenious of religious orders in communicating sanctity - managed and promoted "Jesuit sanctity" in a process of identity definition and expression that was always accommodated, according to the time, place, and circumstances. 